\title{
POSTKOLONIALIZM. NOWA FALA
}

\author{
EMILIA KLEDZIK \\ (Uniwersytet im Adama Mickiewicza w Poznaniu)
}

Kiedy sześć lat temu redakcja „Porównań" pracowała nad pierwszym numerem poświęconym studiom postkolonialnym w Polsce i w Europie Środkowej, prawdopodobnie żaden z członków redakcji, ale i czytelników naszego pisma, nie spodziewał się, że ta nowa, przeszczepiona z Zachodu metodologia okaże się jedną z głównych osi współczesnej humanistyki w Polsce i że będzie jej poświęcony niemal każdy kolejny numer naszego poznańskiego pisma komparatystycznego. W 2008 roku przeważały jeszcze, wzbudzone publikacjąapelem amerykańskiej slawistki, Claire Cavanagh, głosy, o konieczności zachowania dystansu wobec teoretycznego "nowinkarstwa”, a perspektywa porównania kondycji postsowieckiej części Europy z odległymi obszarami dawnych zamorskich kolonii, wydawała się niemal metodologiczną herezją.

A przecież grunt pod postkolonialną rewolucję w polskiej humanistyce położono już wiele lat wcześniej. W 1995 roku Tomasz Szkudlarek, teoretyk pedagogiki negatywnej, pedagog edukacji regionalnej i rzecznik emancypacji $\mathrm{w}$ praktykach edukacyjnych pisał o postkolonializmie:

Jest to teoria niemal gotowa do wykorzystania $\mathrm{w}$ analizach wszelkich problemów ujmowanych w relacji do „zmiany społecznej”. „Zmianę" owa teoria mieści bowiem w swoim wnętrzu - nie jest niczym innym, jak właśnie wizją dynamiki zmiany. Z perspektywy tej teorii można mówić o edukacji w jej podwójnej roli: jako o sile zniewalającej, kolonizującej "świat życia” jednostek i społeczności, oraz jako o czynniku dekolonizacji, wyzwolenia, emancypacji ${ }^{1}$.

Autorzy kilku reform systemu edukacji w Polsce nie skorzystali lekcji z emancypacyjnego dobrodziejstwa teorii postkolonialnej - dość przypomnieć głośny przed paru laty spór o miejsce dla Witolda Gombrowicza w kanonie lektur szkolnych. Można nawet powiedzieć, że w tym kontekście praktykę edukacyjną dotknął swoisty „backlash”. Jeśli jednak chodzi o inne dyscypliny nauk społecznych i humanistycznych, język postkolonialności (lub - w jej, wciąż dyskutowanej,

1 T. Szkudlarek, Wydarzenie, urzeczywistnienie, różnica: edukacyjna autokreacja społeczeństwa. W: Różnica, tożsamość, edukacja. Szkice z pogranicza. Red. T. Szkudlarek. Kraków 1995, s. 11. 
udomowionej wersji - język postzależności) sprawdził się jako sposób mówienia o polskiej i środkowoeuropejskiej transformacji ustrojowej, o kulturowej „postsowieckości” tego obszaru. Złożył się na to szereg okoliczności, jakie przed „zwrotem postkolonialnym" zaszły na niwie teorii. Należy do nich zaliczyć kryzys dekonstruktywizmu, popularność studiów kulturowych i „zwrot antropologiczny”, rehabilitujący podmiotowość jako kategorię interpretacyjną i dostrzegający w literaturze - podobnie jak $\mathrm{w}$ relacji etnograficznej - domenę fikcji, rozumianej jako narzędzie do opisywania i konstruowania tożsamości. Okolicznością sprzyjającą stała się także moda na interdyscyplinarość, bez której nie doszłoby do zbliżenia tak wielu dziedzin nauki pod egidą postkolonializmu, wreszcie - diagnoza o kryzysie paradygmatu romantycznego, w którym postkolonialiści dostrzegają mutację antykolonialnego resentymentu.

Największe obawy, jakie towarzyszyły postkolonialnemu przeszczepowi w Polsce i Europie Środkowej, dotyczyły mało nowatorskiej perspektywy badawczej, serwilizmu w stosunku do zachodniej myśli teoretycznej, a nawet ryzyka odświeżenia esencjalistycznego języka martyrologii i mitów narodowych. Sześć lat po pierwszych postkolonialnych publikacjach w "Porównaniach” można jednak stwierdzić z całą pewnością, że obawy te były nieuzasadnione, a naukowa rzeczywistość zaowocowała efektami przeciwnymi do projektowanych. Postkolonializm jest jedyną optyką, w której uwidoczniają się fluktuacje środkowoeuropejskich dominacji/podporządkowań, że doczekał się już obszernej dyskusji i znaczącego miejsca na mapie lokalnych treorii i wreszcie - jako promotor lektury podejrzliwej - przyczynił się do rewizji wciąż żywych w tym rejonie świata dyskursów etnocentrycznych (vide: tzw. dyskurs kresowy).

Do największych jednak zasług tej metodologii należy zaliczyć szansę na nową odsłonę badań komparatystycznych. Studia postkolonialne, posługujące się takimi kategoriami jak: pogranicza, hybrydyzacja, przemoc epistemiczna, mimikra, przepisanie, migracja, zależność, postzależność, platformy dla studiów regionalnych, oferują inną, nowocześniejszą perspektywę poznawczą od dotychczasowych filologii narodowych i slawistyk. Komparatystyka dyskursów postkolonialnych - termin Bogusława Bakuły - jest szeroko zakrojonym projektem, dotyczącym sposobu obchodzenia się z symbolicznym i materialnym dziedzictwem dawnych sytuacji zależności, wytworzonym na jego podstawie imagologicznym instrumentarium, opartym na takich nietradycyjnych dla badań filologicznych źródłach, jak historia mówiona, pamięć, artefakty kulturowe, publicystyka. Komparatystyka dyskursów postkolonialnych bada stopień i sposób rozpoznania historycznych traum, stosunek do mitów narodowych, instrumentalizację pamięci, formy "rekonstruowania” genologii narodowych i wreszcie - obraz „Innych”, w opozycji do których konsoliduje się wspólnota. Przekonanie, że Europa Środkowa jest wielokulturowym domem dla rozlicznych nacji i wyznań, w równym stopniu obdarzonych "postkolonialną wrażliwością", płynącą z bycia subalternem, wynika z naj- 
lepszym przypadku z naiwności, w najgorszym - jest strategią orientalizacji, właściwą niektórym idiolektom pisarskim. Taka środkowoeuropejska mapa punktów zapalnych lub rozejmów i równolegle prowadzonych dyskursów: ostalgicznego, rewindykacyjnego, narodowego, ksenofobicznego, równościowego, tożsamościowego, emancypacyjnego, regionalistycznego czy globalizacyjnego zapełnia „białą plamę na mapie teorii", o której pisała Claire Cavanagh. Nie tyle jednak za pomocą dyskursu sztucznie przeszczepionego z amerykańskiej akademii, ale z uwzględnieniem zjawisk dobrze zakorzenionych lokalnie i z korzyścią dla rozwijającej się w nim humanistyki.

Numer „Porównań”, który przedkładamy Czytelnikom, jest - ponownie - zaledwie probierzem komparatystycznych praktyk postkolonialnych, jakie są możliwe $\mathrm{w}$ tym obszarze (naukowym i geograficznym). To pierwszy tom pokłosia konferencji pt. Kultura sytuacji postkolonialnej², która odbyła się w Instytucie Filologii Polskiej Uniwersytetu im. Adama Mickiewicza w Poznaniu 6-7 maja 2013 roku. Otwiera go tekst Doroty Kołodziejczyk, dotyczący krytycznego potencjału studiów postkolonialnych w Europie Środkowo-Wschodniej i miejsca, w którym ten dyskurs łączy się z krytyką globalizacji. Razem z tekstem Neila Lazarusa, uznanego amerykańskiego postkolonialisty, polemizuje z widmem uniwersalizmu studiów postkolonialnych, w których zanika to, co lokalne i peryferyjne. Przeciwnie argumentuje Kołodziejczyk - kategorie postkolonialne są zawsze lokalne. Na apel o stworzenie kontrapunktu dla narracji tożsamościowej, której zakładnikiem bywa w Polsce postkolonialnizm odpowiada tekst Mieczysława Dąbrowskiego, traktujący o specyfice nowej polskiej literatury emigracyjnej (lub - jak chce Dąbrowski migracyjnej), która porzuca etnosymboliczny model tożsamości narodowej i zanurza się w gąszczu świadomie estetycznie uruchamianych klisz i stereotypów.

W numerze nie brak głosów zdystansowanych. Mykoła Riabczuk, analizując postkolonialną sytuację Ukrainy, wskazuje na ograniczenie tej metodologii, która w Europie Środkowo-Wschodniej wiąże się z koniecznością porzucenia kategorii "rasy". To zjawisko, nazwane przez Ewę Thompson „białym kolonializmem”, jest jednak $\mathrm{w}$ pozostałych kwestiach polityczno-ekonomiczno-kulturowych $\mathrm{w}$ pełni kompatybilne z praktyką zachodnioeuropejskich kolonializmów. Paweł Wolski w nawiązaniu do zarzutów o odtwórczym charakterze postkolonialnych rozpoznań w Europie Środkowej - pisze natomiast o swoistej autokolonizacji polskich studiów nad Zagładą.

Polskie tropy postkolonialności i postzależności podejmuje tekst Hanny Gosk stawiający ważną diagnozę o polskiej literaturze najnowszej uwięzionej w spetryfikowanej „narracji ojczyźnianej”, która wprawdzie zamieniła wymiar pedago-

2 Konferencja odbyła się w ramach projektu: Dyskurs postkolonialny w Europie Środkowo-Wschodniej 1991-2011: Polska, Węgry, Stowacja, Ukraina. Literatura, eseistyka, stan badań w latach 2012-2014. NPRH 12H 1100188. 
giczny na performatywny (Homi Bhabha), jest jednak wciąż zakładnikiem tego samego paradygmatu. Wśród necessary fictions - termin Homiego Bhabhy przypominany polskiej publiczności przez Ewę Thompson - narracji, które mają służyć rekonstruowaniu wspólnotowych korzeni narodu - w polskiej literaturze najnowszej Emilia Kledzik wskazuje na śladowe fabuły postsłowiańskie, mit sarmatyzmu oraz mit kompatybilności przełomów politycznych 1918 i 1989 roku. Agnieszka Czyżak zajmuje się subwersywnym potencjałem literackich kreacji PRL-u autorstwa Michała Witkowskiego, widzianych przez pryzmat ironii i nostalgii.

Postkolonialną, ale i właściwą „Porównaniom” specjalnością są analizy tekstów kultury zapisanych w różnych kodach semiotycznych. Refleksja Dobrochny Dabert dotyczy wizualnych i narracyjnych strategii kolonizowania Innego w filmie, którego leitmotiv stanowi dialog międzykulturowy. Jacek Nowakowski rekapituluje filmowe prezentacje Orientu $\mathrm{w}$ polskim kinie powojennym. Aleksandra Muga dotyka newralgicznego wątku imperialnej pamięci Węgrów, znajdującego swoje odzwierciedlenie w prezentacjach Siedmiogrodu w kinie węgierskim. Tekst Jakuba Lewickiego systematyzuje środkowoeuropejskie praktyki obchodzenia się z wielokulturowym charakterem zabytków architektonicznych, wskazując pozytywne oraz negatywne przykłady ich zagospodarowywania. Piotr Dobrowolski natomiast zajmuje się dyskursem dotyczącym polskich tzw. Ziem Odzyskanych, wykorzystywanym twórczo przez współczesnych reżyserów teatralnych, do „oddania głosu" dotychczasowym ofiarom polskiej zbiorowej amnezji.

Minęło niemal 50 lat od czasu, kiedy Stanisław Barańczak pisał o poezji, że powinna być demaskacją, krytycyzmem i nieufnością. W tym czasie polska humanistyka odzyskała światopoglądową wolność, która pozwoliła ponownie zawędrować w obszary tak nielubianego przez nowofalowców estetyzmu, tym razem - postmodernistycznego - by ostatecznie powrócić do Barańczakowej „nieufności” - tym razem wobec tekstu, wobec podmiotu, wobec tekstualności. Lektura postkolonialna być może właśnie dlatego tak dobrze przyjęła się w Polsce, że tutejsi badacze dobrze pamiętają ówczesne postulaty bycia podejrzliwym - wobec głosu płynącego z trybun, wobec uładzonych formuł, wobec jakichkolwiek form ideologizacji języka sztuki, jego opresywnego, ale i emancypacyjnego potencjału. Te często bolesne - rozpoznania, dotyczące środkowoeropejskiego imaginarium wspólnot, traum, wykluczeń i marzeń o imperium, to wciąż lokalnie niedokończona lekcja. „Porównania” ponownie pomagają ją odrobić. W imieniu Redakcji zapraszam do lektury! 